\title{
Pengembangan Modul Fisika Materi Gerak Parabola Berbasis Generative Learning
}

\author{
Destia Mareta Dyah Santoso ${ }^{1}$, Winarti ${ }^{2}$ \\ 1,2 Program Studi Pendidikan Fisika, UIN Sunan Kalijaga Yogyakarta \\ Jl. Marsda Adisucipto No 14, Sleman, D.I. Yogyakarta \\ Email: destiamaretadyahsantoso@gmail.com
}

\begin{abstract}
Generative learning is a learning strategy with constructivism approach, where the students have the opportunity to construct their own knowledge. The aims of this study is 1) to design a physics module based on generative learning for the topic of parabolic motion. 2) to know the quality of the physics module based on generative learning for the topic of parabolic motion. 3) to know students responses about the developed physics module. This study is an $R \& D$ research with procedures which adapts the development procedures of the 4D model, this model consists of define, design, develop, and disseminate. The data collecting technique in this study is the non-test technique with a questionnaires method. The instruments which used are validation sheets, module evaluation sheets, and students responses questionnaires. The result of this study are 1) it has been developed a physics module for the topic of parabolic motion based on generative learning 2) the quality oh physics module based on generative learning, based on the assessment of physics material experts, media experts, physics teachers has the excellent result with an average score 3,44; 3,66; and 3,64. And 3) the student's responses in a limited test show that the average students give agreement to the developed product with average score 0,95. These study results show that a physics module based on generative learning for parabolic motion topic is suitable yo use for one of the self-learning references.
\end{abstract}

Keywords: generative learning, parabolic motion, and physics module.

\begin{abstract}
Abstrak: Generative Learning merupakan strategi pembelajaran dengan pendekatan kontruktivisme, dimana peserta didik dapat memperoleh kesempatan untuk mengkontruksi pengetahuannya sendiri. Tujuan penelitian ini adalah untuk 1) mendesain modul fisika berbasis generative learning pada materi pokok gerak parabola; 2) mengetahui kualitas modul fisika berbasis generative learning pada materi pokok gerak parabola; 3) mengetahui respon peserta didik terhadap modul fisika yang telah dikembangkan. Penelitian ini merupakan penelitian R \& D dengan prosedural yang mengadaptasi prosedur pengembangan perangkat model 4-D, yakni define, design, develop, dan disseminate. Teknik pengumpulan data penelitian ini adalah teknik non tes dengan metode angket. Adapun instrumen yang digunakan berupa lembar validasi, lembar penilaian modul, dan angket respon peserta didik. Hasil penelitian ini antara lain: 1) telah dihasilkan modul fisika materi gerak parabola berbasis generative learning; 2) kualitas modul fisika berbasis generative learning berdasarkan penilaian ahli materi, ahli media, dan guru fisika memiliki kategori Sangat Baik dengan skor rerata berturut-turut 3,44; 3,66; dan 3,64 ; dan 3) respon peserta didik pada uji terbatas menunjukkan bahwa rata-rata peserta didik menyatakan Setuju dengan adanya produk yang dikembangkan dengan skor rerata 0,98 dan respon peserta didik pada uji luas menunjukkan bahwa peserta didik menyatakan Setuju dengan adanya produk yang dikembangkan dengan skor rerata 0,95 . Hasil penelitian ini menunjukkan bahwa modul fisika berbasis generative learning pada materi gerak parabola layak dijadikan sebagai salah satu sumber belajar mandiri.
\end{abstract}

Kata kunci: modul fisika, generative learning, gerak parabola. 


\section{Pendahuluan}

Fisika sebagai bagian dari sains (IPA) yang memiliki peran penting dalam meningkatkan kualitas Pendidikan. Anaperta (2015) menyatakan bahwa fisika merupakan bagian dari sains yang mempelajari fenomena dan gejala alam secara empiris, logis, sistematis dan rasional yang melibatkan proses dan sikap ilmiah. Peserta didik akan lebih mudah memahami konsep dan prinsip fisika yang dihubungkan dengan fakta atau fenomena yang terjadi dalam kehidupan sehari-hari.

Penggunaan berbagai macam strategi pembelajaran dapat mempengaruhi proses pembelajaran. Sharfina dkk (2017) menyatakan bahwa pembelajaran fisika yang hanya berorientasi menghapal rumus dan konsep tidak akan memberikan makna yang berarti bagi peserta didik, namun pembelajaran fisika diharapkan menciptakan kegiatan layaknya seorang ilmuan untuk membangun konsep dan menerapkan konsep yang didapatkan. Kegiatan layaknya seorang ilmuan tersebut dapat dilakukan dalam proses pembelajaran di sekolah. Sani (2017) menyatakan bahwa pendidik harus memiliki kemampuan untuk merumuskan pertanyaan yang sangat dibutuhkan untuk memancing peserta didik berpikir.

Peserta didik harus memiliki beberapa keterampilan untuk membangun konsep secara mandiri. Kivunja (2015) menyatakan bahwa dalam dunia kerja abad-21 sangat diperlukan keterampilan seperti berpikir kritis, kerjasama tim, kreatifitas, komunikasi, informasi, dan kemandirian belajar.

Untuk membangun pemahaman peserta didik secara mandiri, pendidik harus melibatkan penuh peran peserta didik dalam proses pembelajaran. Kuswana (2013) menyatakan bahwa perlu suatu pendekatan, strategi, dan metode yang selaras dengan kebutuhan pencapaian tujuan dan potensi peserta didik. Syirlatifah (2014) menyatakan bahwa dengan menggunakan pembelajaran generatif, peserta didik akan lebih aktif dalam mengikuti proses pembelajaran dan akan memahami betul konsep dasar dari materi yang diajarkan karena mereka yang menemukan sendiri pengetahuan barunya yang kemudian dihubungkan dengan pengetahuan yang diberikan oleh pendidik sehingga mereka akan lebih mudah menyelesaikan soal-soal yang memiliki kesulitan yang tinggi sehingga hasil belajarnya dapat meningkat.

Wittrock (1992) menyatakan bahwa intisari dari generative learning ialah otak yang menerima informasi secara aktif untuk mengkonstruksi suatu interpretasi dari informasi tersebut. Firmansyah (2017) menyatakan bahwa strategi generative learning berbasis pada pandangan konstruktivisme, dengan asumsi dasar bahwa pengetahuan dibangun dalam pikiran peserta didik.

Trianto (2010) menyatakan contructivism (kontruktivisme) merupakan landasan berpikir (filosofi) pendekatan konstektual, yaitu bahwa pengetahuan dibangun oleh manusia sedikit demi sedikit, yang hasilnya diperluas melalui konteks yang terbatas dan tidak sekonyongkonyong. Dalam proses pembelajaran kontruktivisme peserta didik membangun sendiri pengetahuan mereka melalui keterlibatan aktif dalam proses kegiatan belajar mengajar, disini peserta menjadi pusat perhatian bukan pendidik. Jatisunda (2017) menyatakan pendekatan kontruktivisme memberikan peran yang berbeda kepada pendidik dan peserta didik, dalam hal ini peserta didik lebih berperan aktif.

Dari pendapat di atas dapat disimpulkan bahwa Generative Learning dapat meningkatkan peran aktif peserta didik dalam proses pembelajaran. Wena (2008) menyatakan strategi Generative Learning terdiri dari empat tahapan, yaitu eksplorasi (pendahuluan), pemfokusan, tantangan (tahap pengenalan konsep), dan penerapan konsep. Agnafia (2017) menyatakan tahapan generative learning dapat meningkatkan kemampuan berpikir kritis, karena tahapannya dapat mengembangakan daya nalar tingkat tinggi. 
Kenyataan yang ditemukan berdasarkan observasi di SMA Negeri 2 Banguntapan, dalam proses pembelajaran pendidik menggunakan buku teks dari penerbit. Sani (2017) menyatakan bahwa pendidik yang kreatif harus terampil menyajikan secara langsung dan mengatur cara agar siswa merespon. Namun, faktanya pendidik hanya terpaku menggunakan buku teks dan menampilkan materi di layar proyektor saja. Pendidik dalam menyampaikan materi pembelajaran hanya mengikuti urutan yang telah ada di dalam buku teks dan di akhir pembelajaran pendidik menyediakan soal untuk latihan yang di ambil dari buku teks tersebut.

Berdasarkan analisis dokumen, buku teks tersebut hanya lebih ditekankan pada misi penyampaian pengetahuan/fakta belaka, tidak mempertimbangkan bagaimana buku tersebut mudah dipahami oleh peserta didik. Akibatnya, peserta didik sulit memahami buku yang dibacanya dan dirasa membosankan. Sebenarnya pendidik bisa membuat bahan ajar yang sesuai dengan peserta didik, namun di SMA Negeri 2 Banguntapan tidak tersedia bahan ajar yang dikembangkan oleh pendidik. Salah satu bahan ajar yang dapat dikembangkan oleh pendidik ialah modul. Dian, dkk (2016) menyatakan bahwa modul adalah bahan ajar yang disusun secara sistematis dengan isi yang mudah dipahami peserta didik untuk belajar secara mandiri.

Akibat yang timbul dari permasalahan buku teks tersebut ialah kurangnya motivasi belajar peserta didik, penyelesaian tugas peserta didik tidak sesuai waktu yang ditentukan, dan hasil tes peserta didik menunjukkan nilai yang rendah. Berdasarkan observasi di SMA Negeri 2 Banguntapan hasil Ulangan Harian pada materi Gerak Parabola yang masih sangat rendah, yaitu besar prosentase peserta didik yang telah tuntas belajar hanya sebesar $23,7 \%$.

Untuk meningkatkan kualitas pembelajaran dapat dilakukan beberapa hal, salah satunya dengan penerapan pembelajaran individual, yang akan memberikan kepercayaan penuh terhadap kemampuan individu untuk belajar secara mandiri.

Berdasarkan uraian di atas, untuk mengatasi permasalahan yang terjadi di SMA Negeri 2 Banguntapan diperlukan sebuah bahan ajar berbentuk modul yang mendukung proses pembelajaran sehingga dapat memfasilitasi peserta didik untuk menghubungkan materi pembelajaran dengan fenomena yang terjadi dalam kehidupan sehari-hari. Modul juga dapat digunakan untuk memperjelas dan mempermudah penyajian materi pelajaran agar tidak terlalu bersifat verbal serta mengatasi keterbatasan waktu, ruang, dan daya indra. Modul yang dikembangkan peneliti ialah modul fisika berbasis generative learning pada materi gerak parabola. Telah dijelaskan di atas bahwa generative learning merupakan strategi pembelajaran dimana belajar aktif berpartisipasi dalam proses belajar dan mengkontruksi makna dan informasi yang ada disekitarnya berdasarkan pengetahuan awal dan pengalaman yang dimiliki oleh peserta didik.

\section{Metode Penelitian}

Penelitian ini merupakan penelitian Research and Development (R\&D) yaitu metode penelitian yang digunakan untuk menghasilkan produk Pendidikan. Penelitian yang dilakukan merupakan pengembangan modul berbasis generative learning. Penelitian pengembangan ini menggunakan model pengembangan 4D (Define, Design, Development, and Dissemination) yang dikembangkan oleh S. Thiagarajan, Dorothy S. Semmel, dan Melvyn I Semmel (1974).

Teknik pengumpulan data penelitian ini adalah teknik non tes dengan metode angket. Adapun instrumen yang digunakan berupa lembar validasi, lembar penilaian modul, dan angket respon peserta didik.

Subjek penelitian ini terdiri dari 4 validator ( 2 validator instrumen dan 2 validator produk) dan 8 penilai (3 ahli materi, 3 ahli media, dan 2 guru fisika SMA/MA). Untuk mengetahui 
respon peserta didik dilakukan uji terbatas terhadap 10 peserta didik dan uji luas terhadap 52 peserta didik kelas XI MIPA SMA Negeri 2 Banguntapan.

Data yang diperoleh dari penelitian ini adalah data analisis deskriptif yang diperoleh dari kritik dan saran validator, penilai, dan hasil respon peserta didik terhadap modul fisika generative learning.

\section{Hasil dan Pembahasan}

Hasil penelitian ini yaitu produk utama berupa modul pembelajaran fisika berbasis generative learning untuk peserta didik kelas X SMA/MA pada materi Gerak Parabola. Seharusnya penelitian ini melalui empat tahapan, namun dikarenakan keterbatasan waktu dan biaya tahap dissemination tidak dilakukan oleh peneliti. Tiga tahapan yang dilakukan peneliti, yaitu define, design, dan development.

Modul disusun berdasarkan tahapan pada strategi pembelajaran berbasis generative learning. Strategi pembelajaran generative learning dipilih karena peserta didik dapat mengkonstruk pikirannya sendiri. Hal ini sesuai dengan Firmansyah (2017) menyatakan bahwa strategi generative learning berbasis pada pandangan konstruktivisme, dengan asumsi dasar bahwa pengetahuan dibangun dalam pikiran peserta didik.

Wena (2008) menyatakan generative learning memiliki empat tahapan dalam pembelajaran, diantaranya:

(1) Tahap Eksplorasi tahap ini guru membimbing peserta didik untuk melakukan eksplorasi menggunakan panca indera secara maksimal terhadap pengetahuan, ide, atau konsepsi awal yang diperoleh dari pengalaman sehari-hari. Setelah melakukan eksplorasi, peserta didik membuat hipotesis berdasarkan gambar yang telah disediakan, berikut bagian modul yang menggambarkan tahapan eksplorasi adalah sebagai berikut:

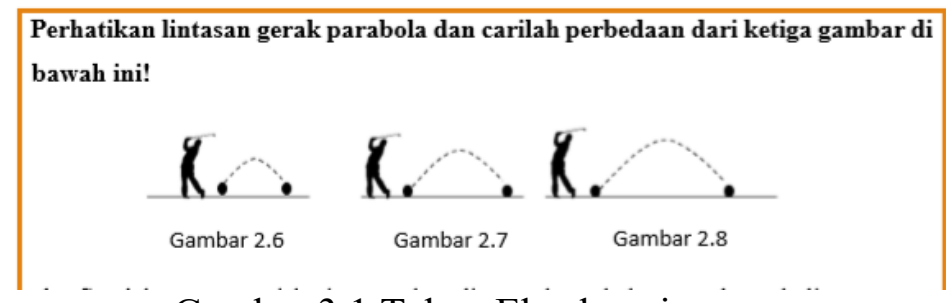

Gambar 3.1 Tahap Eksplorasi

(2) Tahap Pemfokusan, peserta didik melakukan pengujian dari hipotesis melalui kegiatan laboratorium dan guru bertugas sebagai fasilitator yang menyangkut kebutuhan sumber, memberi bimbingan, dan arahan, berikut bagian modul yang menggambarkan tahapan pemfokusan adalah sebagai berikut: 


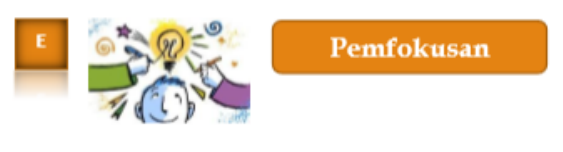

Setelah mengamati gambar $2.6 ; 2.7$; dan 2.8 , kemukakan pendapat kalian mengenai
faktor yang menyebabkan perbedaan lintasan parabola dari gambar tersebut
berdasarkan percobaan!

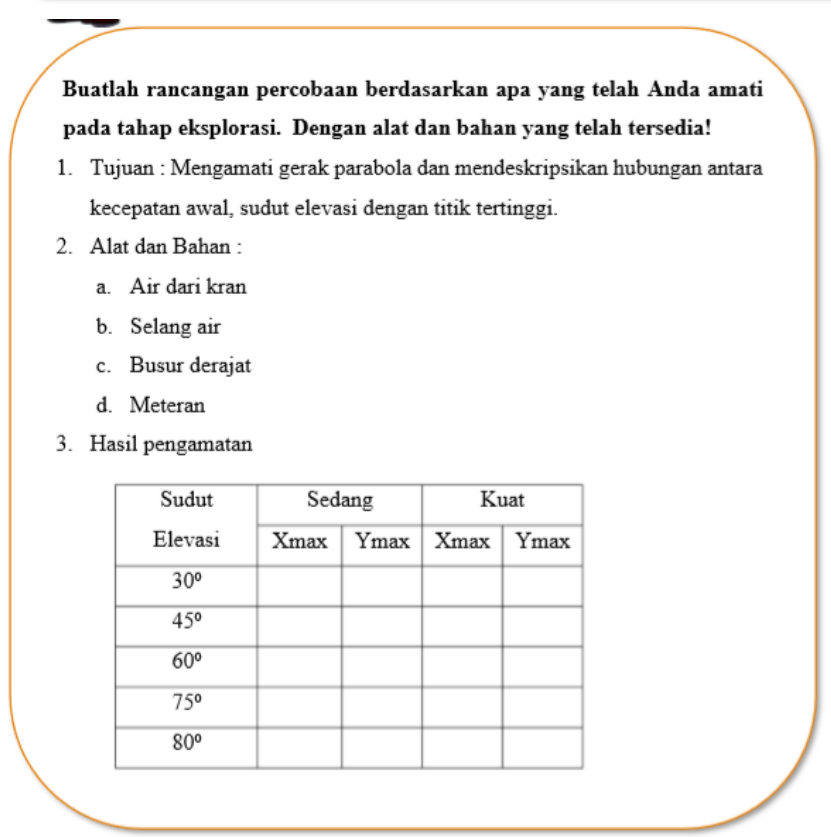

Gambar 3.2 Tahap Pemfokusan

(3) Tahap Tantangan, setelah peserta didik memperoleh data selanjutnya menyimpulkan dan menulis dalam lembar kerja. Dalam tahap ini peserta didik mempresentasikan hasil temuannya melalui diskusi kelas. Peserta didik mengeluarkan ide, kritik, berdebat dan menghargai pendapat teman. guru bertugas sebagai fasilitator, berikut bagian modul yang menggambarkan tahapan tantangan adalah sebagai berikut:

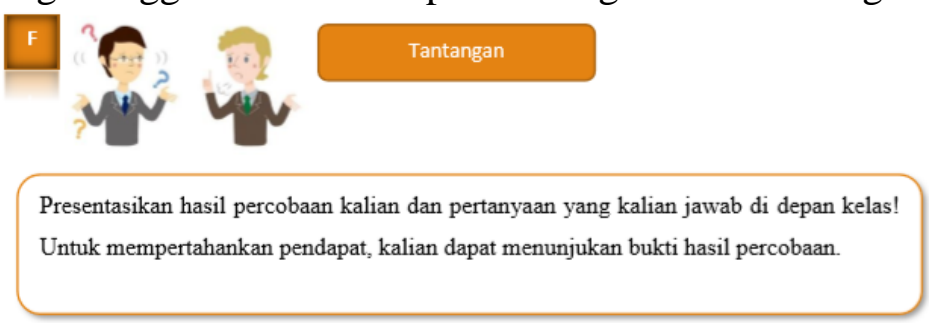

\section{Gambar 3.3 Tahap Tantangan}

(4) Tahap Aplikasi, peserta didik diajak untuk menyelesaikan masalah dengan menggunakan konsep barunya dan mempersiapkan untuk materi selanjutnya, berikut bagian modul yang menggambarkan tahapan aplikasi adalah sebagai berikut: 


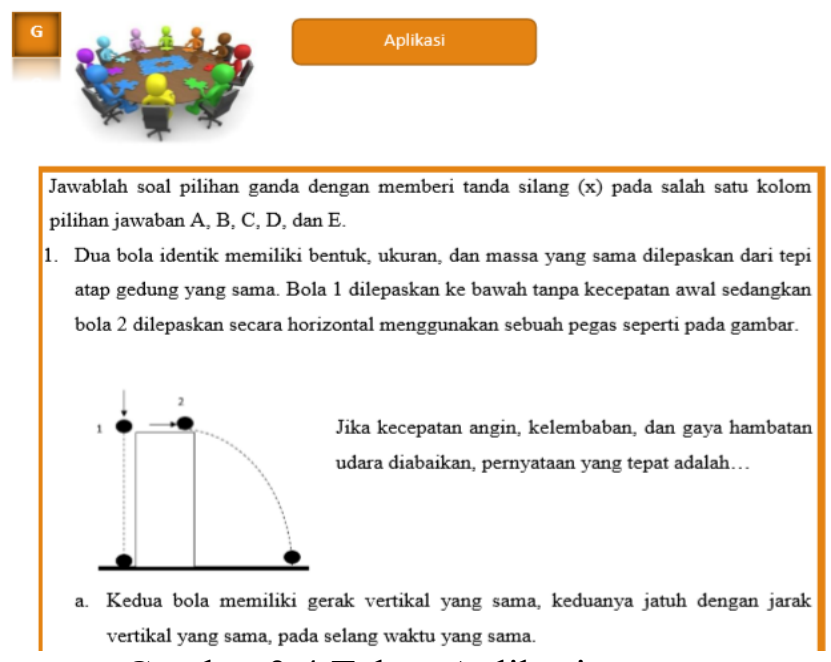

Gambar 3.4 Tahap Aplikasi

Penilaian modul pembelajaran fisika berbasis generative learning melibatkan 3 orang ahli materi, 3 orang ahli media, dan 2 orang guru fisika SMA/MA.

Aspek yang dinilai oleh ahli materi meliputi kebenaran konsep, susunan materi, penilaian, dan generative learning. Penilaian ahli materi terhadap modul keseluruhan diperoleh skor rata-rata 3,44. Berdasarkan aspek yang dinilai, secara keseluruhan modul memiliki kualitas Sangat Baik (SB).

Aspek yang dinilai oleh ahli media meliputi kejelasan dan ketepatan penggunaan gambar, daya tarik modul, bentuk dan ukuran huruf modul, dan bahasa modul. Penilaian ahli media terhadap modul secara keseluruhan diperoleh skor rata-rata 3,66. Berdasarkan aspek yang dinilai, secara keseluruhan modul memiliki kualitas Sangat Baik (SB).

Aspek yang dinilai oleh guru fisika meliputi kualitas isi materi, ilustrasi (gambar, tabel, dan peta konsep), kebahasaan, tampilan, penilaian, generative learning, kelengkapan modul, dan keterlaksanaan. Penilaian guru fisika SMA/MA terhadap modul secara keseluruhan diperoleh skor rata-rata 3,64. Berdasarkan aspek yang dinilai, secara keseluruhan modul memiliki kualitas Sangat Baik (SB).

Adapun perbandingan hasil penilaian modul pembelajaran fisika berbasis generative learning oleh ahli dan guru fisika SMA/MA disajikan dalam gambar 3.5 sebagai berikut:

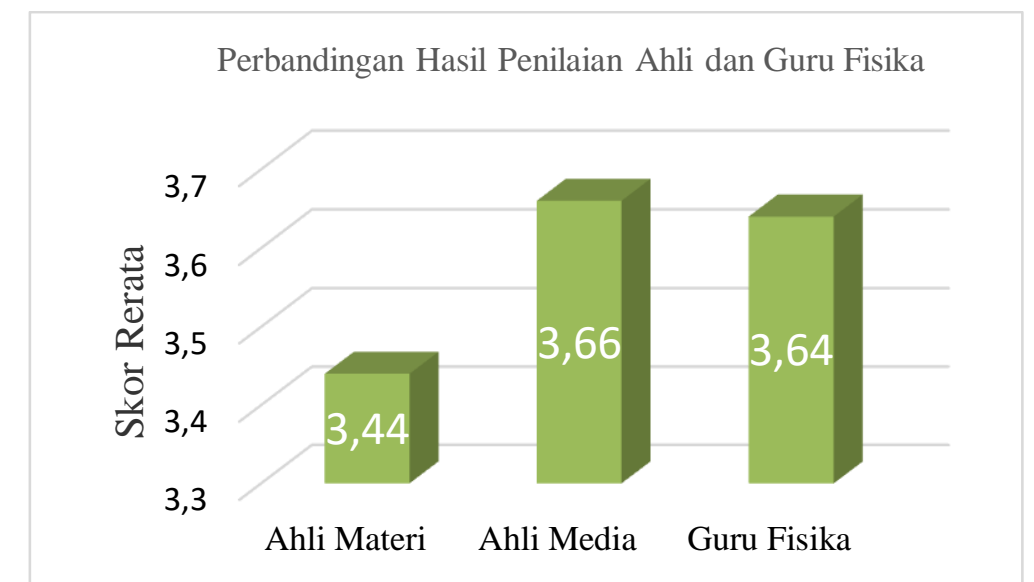

Gambar 3.5 Perbandingan Hasil Penilaian Ahli dan Guru Fisika SMA/MA 
Setelah modul selesai direvisi berdasarkan kritik dan saran penilai, selanjutnya dilakukan penyebaran angket respon peserta didik. Penyebaran angket respon peserta didik dilaksanakan dua kali pada saat uji coba terbatas terhadap 10 peserta didik dan uji luas terhadap 52 peserta didik. Adapun perbandingan hasil respon peserta didik terhadap modul pembelajaran fisika berbasis generative learning pada uji terbatas dan uji luas disajikan dalam gambar 3.6 sebagai berikut:

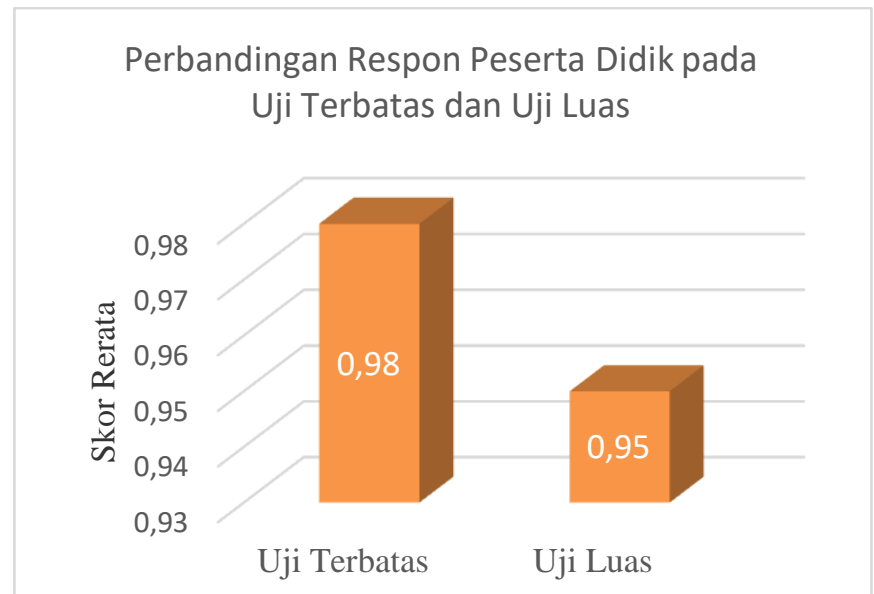

Gambar 3.6 Perbandingan Respon Peserta Didik pada Uji Terbatas dan Uji Luas

Hasil uji coba terbatas peserta didik secara keseluruhan memperoleh skor rerata sebesar 0,98; dan hasil uji coba luas peserta didik secara keseluruhan memperoleh skor raerata sebesar 0,95. Hal ini menunjukkan bahwa dalam uji coba terbatas \& luas peserta didik memberikan respon dengan kategori Setuju. Artinya, modul dapat diterima oleh peserta didik.

Peneliti mengembangkan modul pembelajaran fisika berbasis generative learning dengan tujuan peserta didik dapat berlatih berdiskusi, berpartisipasi, bekerjasama, dan memecahkan masalah-masalah tertentu yang berkaitan dengan kehidupan sehari-hari. Dengan adanya kegiatan yang terdapat di modul pembelajaran fisika tersebut, peserta didik akan memperoleh pengetahuan secara maksimal, karena peserta didik dapat menggabungkan aktivitas otak dan aktivitas tubuh secara bersamaan dalam satu kegiatan belajar mengajar.

\section{Kesimpulan}

Berdasarkan hasil analisis dan pembahasan, maka dapat disimpulkan bahwa (1) Telah berhasil dikembangkan produk berupa modul pembelajaran fisika berbasis generative learning pada materi gerak parabola untuk SMA/MA kelas X semester I; (2) Kualitas modul pembelajaran fisika berbasis generative learning pada materi gerak parabola untuk SMA/MA kelas X semester I berdasarkan penilaian ahli materi, ahli media, dan guru fisika SMA/MA secara keseluruhan sangat baik (SB) dengan rerata skor 3,44 untuk ahli materi; 3,66 untuk ahli media; dan 3,64 untuk guru fisika; (3) Respon peserta didik terhadap modul pembelajaran fisika berbasis generative learning pada materi gerak parabola untuk SMA/MA kelas X semester I pada uji terbatas dan uji luas adalah Setuju (S) dengan rerata skor uji terbatas 0,98 dan uji luas 0,95 serta modul terlaksana dengan baik di kelas.

\section{Saran}

Peneliti menyarankan dalam (1) Pengembangan Modul Berbasis Generative Learning, ini memiliki 4 tahapan, pada setiap tahapan tersebut memiliki kesulitan-kesulitan tersendiri bagi peneliti. Agar peneliti lain tidak mengalami kesulitan, maka peneliti menyarankan pada tahap: 
(a) Eksplorasi, disarankan peneliti lain menghubungkan materi dengan kehidupan sehari-hari. Hal tersebut dilakukan agar peserta didik secara mandiri memahami materi. Untuk dapat menghubungkan materi dengan kehidupan sehari-hari, peneliti harus benar-benar memahami materi yang akan dikembangkan. Pada tahap ini tingkat kreativitas peneliti diuji; (b) Pemfokusan, peneliti menyarankan agar peneliti lain menyiapkan kegiatan praktikum yang berhubungan dengan tahap eksplorasi agar konsep materi peserta didik terbentuk dari kegiatan praktikum tersebut; (c)Tantangan, pada tahap ini proses pembentukan konsep materi peserta didik secara mandiri dengan metode diskusi. Agar tidak terlihat monoton, sebaiknya peneliti lain menambahkan kegiatan lain untuk menunjang proses pembentukan konsep materi tersebut; (d) Aplikasi, peneliti menyarankan untuk membuat latihan soal yang berhubungan dengan kegiatan pada tahap-tahap sebelumnya, agar dapat mengetahui kemampuan peserta didik, dan (2) saran peneliti terhadap pemanfaatan modul berbasis generative learning, hasil dari pengembangan modul pembelajaran fisika berbasis generative learning dapat digunakan oleh peserta didik sebagai salah satu referensi untuk belajar mandiri khususnya pada materi gerak parabola. Modul ini juga dapat digunakan dalam proses kegiatan belajar mengajar di sekolah, namun pendidik harus menciptakan suasana belajar yang menyenangkan agar peserta didik mau berargumen dan berpikir. Jika dalam proses kegiatan belajar mengajar peserta didik mengalami kesulitan dalam berargumen, maka pendidik harus membantu peserta didik untuk berpikir dengan memberikan petunjuk agar peserta didik dapat memiliki gambaran mengenai materi yang sedang didiskusikan.

\section{DAFTAR PUSTAKA}

Abidin, Y. 2013. Desain Sistem Pembelajaran dalam Konteks Kurikulum 2013. Bandung: PT Refika Aditama.

Agnafia dkk. 2017. Pengembangan Modul Berbasis Generative Learning pada Materi Keanekaragaman Hayati untuk Meningkatkan Kemampuan Berpikir Kritis Siswa SMA Negeri 1 Kedunggalar Ngawi. Jurnal Inkuiri, Vol 6, No 2 (hal 67-82)

Anaperta, M. 2015. Praktikalitas Modul Fisika SMA Berbasis Model Pembelajaran Generatif pada Materi Listrik Dinamis Terintegerasi Kelistrikan Jantung. Jurnal Riset Fisika Edukasi dan Sains, Vol 2, No 1 (2015) 23-32.

Arifin, Z. 2011. Konsep dan Model Pengembangan Kurikulum. Bandung: PT Remaja Rosdakarya.

Depdiknas. 2003. Undang-undang RI Nomor 20, Tahun 2003, tentang Sistem Pendidikan Nasional.

Depdiknas. 2008. Penulisan Modul. Direktorat Tenaga Kependidikan Dirjen Peningkatan Mutu Pendidikan dan Tenaga Kependidikan.

Dian Putri Kusuma, Arif Maftukhin, Nur Ngazizah. 2016. Pengembangan Modul Pembelajaran Fisika Berbasis Joyfull Learning Guna Meningkatkan Keaktifan dan Hasil Belajar Siswa Kelas XI TP D SMK TKM Purworejo Tahun Pelajaran 2015/2016. Jurnal Radiasi, 8 (1) 1-11.

Djamarah, Syaiful Bahri dan Aswan Zain. 1995. Strategi Belajar Mengajar. Jakarta: PT Rineka Cipta.

Firmansyah, Eka. 2017. Efektifitas pembelajaran Generatif terhadap Kemampuan Matematisasi Siswa di SMP. Jurnal Nasional Pendidikan Matematika, Vol. 1, No. 1, Hal 43.

Fisher, A. 2009. Berpikir Kritis : Sebuah Pengantar. Jakarta:Erlangga.

Hamdani. 2011. Strategi Belajar Mengajar. Bandung: Pustaka Setia.

Irwandani, Rofiah. 2015. Pengaruh Model Pembelajaran Generative terhadap Pemahaman 
Konsep Fisika Pokok Bahasan Bunyi Peserta Didik MTS Al-Hikmah Bandar Lampung. Jurnal Ilmiah Pendidikan Fisika AL-BiRuNi, 4(2): 165-177.

Jatisunda. 2017. Pengaruh Pendidikan Kontruktivisme terhadap Pemecahan Masalah Matematik Peserta Didik (Studi Quasi Eksperimen terhadap Peserta Didik Kelas VIII SMP Negeri 1 Talaga Tahun Pelajaran 2015/2016). Jurnal THEOREMS, Vol. 2 No.1, hal. 57-66

Kuswana, W.S. 2013. Taksonomi Berpikir. Bandung: PT Remaja Rosdakarya Offset. Mulyatiningsih, E. 2012. Metode Penelitian Terapan Bidang Pendidikan. Bandung: Alfabeta.

Riduwan dan Akdon. 2013. Rumus dan Data dalam Aplikasi Statistika untuk Penelitian Administrasi Pendidikan Bisnis Pemerintahan Sosial Kebijakan Ekonomi Hukum Manajemen Kesehatan. Bandung: Alfabeta.

Sanjaya, W. 2007. Strategi Pembelajaran Berorientasi Standar Proses Pendidikan. Jakarta: Prenada Media.

Sanjaya, W. 2008. Perencanaan dan Desain Sistem Pembelajaran. Jakarta: Kencana.

Sharfina, dkk. 2017. Model Pembelajaran Generatif terhadap Peningkatan Keterampilan Proses Sains Siswa Kelas X. Jurnal Pendidikan Sains Indonesia, Vol. 05, No. 01, hlm 102-106.

Sudjana, N. 2010. Penilaian Hasil dan Proses Belajar Mengajar. Bandung: Rosdakarya.

Sugiono. 2013. Metode Penelitian Pendidikan (Pendekatan Kuantitatif Kualitatif dan R\&D). Bandung: Alfabeta.

Sukiman. 2012. Pengembangan Media Pembelajaran. Yogyakarta: Pustaka Insan Madani.

Suprihatiningrum, J. 2013. Strategi Pembelajaran: Teori dan Aplikasi. Yogyakarta: Ar Ruzz Media.

Trianto. 2007. Model Pembelajaran Terpadu dalam Teori dan Praktek. Surabaya: Prestasi Pustaka.

Trianto. 2010. Mendesain Model Pembelajaran Inovatif-Progresif. Jakarta: Kencana Prenada Media Group

Wena, M. 2008. Strategi Pembelajaran Inovatif Kontemporer: Suatu Tinjauan Konseptual Operasional. Jakarta Timur: PT Bumi Aksara.

Widoyoko, S. Eko Putro. 2012. Teknik Penyusunan Instrumen Penelitian. Yogyakarta: Pustaka Pelajar.

Wittrock, Merlin C. 1992. Generative Learning Processes of The Brain. Journal of Educational Psychologist, 27(4): 531-541. 